\title{
NEW RESEARCH RESULTS IN THE LOWER AND MIDDLE SECTION OF THE LOSOSINA VALLEY (WIERNA RZEKA) HOLY CROSS MOUNTAINS, POLAND
}

DOI: https://doi.org/10.18509/AGB.2021.03

UDC: $551.432 .46 .04 / .07(438)$

\section{Tomasz Kalicki ${ }^{1}$, Mariusz Chrabąszcz ${ }^{2}$, Sławek Chwałek ${ }^{2}$, Dmitry Tsvirko ${ }^{3}$, Krzysztof Żurek $^{2}$, Piotr Biesaga ${ }^{2}$, Pawel Przepióra ${ }^{1}$}

\author{
${ }^{I}$ Institute of Geography and Environmetnal Sciences, Jan Kochanowski University in Kielce, Poland \\ ${ }^{2}$ Student Science Club of Geomorphologists ,ZZloty Bażant”, Jan Kochanowski University in Kielce, Poland \\ ${ }^{3}$ Geodynamics and Paleogeography Laboratory, The National Academy of Sciences of Belarus, Belarus
}

corresponding author: biesaga.piotr@onet.pl

submitted: 10.04.2020

accepted: 12.06 .2020

published: 30.09 .2020

\begin{abstract}
The study area is located in the Przedbórz-Małogoszcz Range, the natural extension of the Holy Cross Mountains to the west. The valley is filled with Pleistocene sands and gravels of the Vistulian glaciation as well as periglacial sands and river gravels. The youngest sediments on the studied section are the Holocene sands with mud deposits, on which organic silt and peat was formed [1]. In the valley floor relief is clearly marked by the different ages generations of paleomeanders. The GPR analyzes of the valley floor have shown a dense network of different ages palaeochannels that are more or less visible in the morphology. The results of geophysical analyzes allow for precise location of smaller palaeochannels not previously detected during the field reconnaissance and cartographic material query.
\end{abstract}

Keywords: Łososina River, GPR analyzes, climate changes.

\section{INTRODUCTION}

The Lososina Valley is located in the southwestern part of the Świętokrzyskie voivodeship (Fig. 1). The source sections of the river are located in the Końskie district, the middle section is for the most part in the Kielce district, while the section from Kopaniny to the mouth of the river to Biała Nida River is located in the Jędrzejów district. The Łososina River flows through the Suchedniów Plateau, which is part of the Kielce Upland, as well as the Łopuszno Hills and the PrzedbórzMałogoszcz Range, as the part of Przedbórz Upland
[2] [3]. Lososina is a 4th order river, the longest $(39.7 \mathrm{~km})$, left tributary of Biała Nida The Nida River area within the boundaries of the Lososina (Wierna Rzeka River) catchment area connects the main watercourse that drains the southern and western parts of the Holy Cross Mountains and the Kielce Upland area. A characteristic element of the Łososina River are the gap sections of the valley through the Małogoszcz Range and Czubatka Peak (Fig. 2). In the flood plains area are often wetlands in which small peatbogs are formed [4] [5]. 


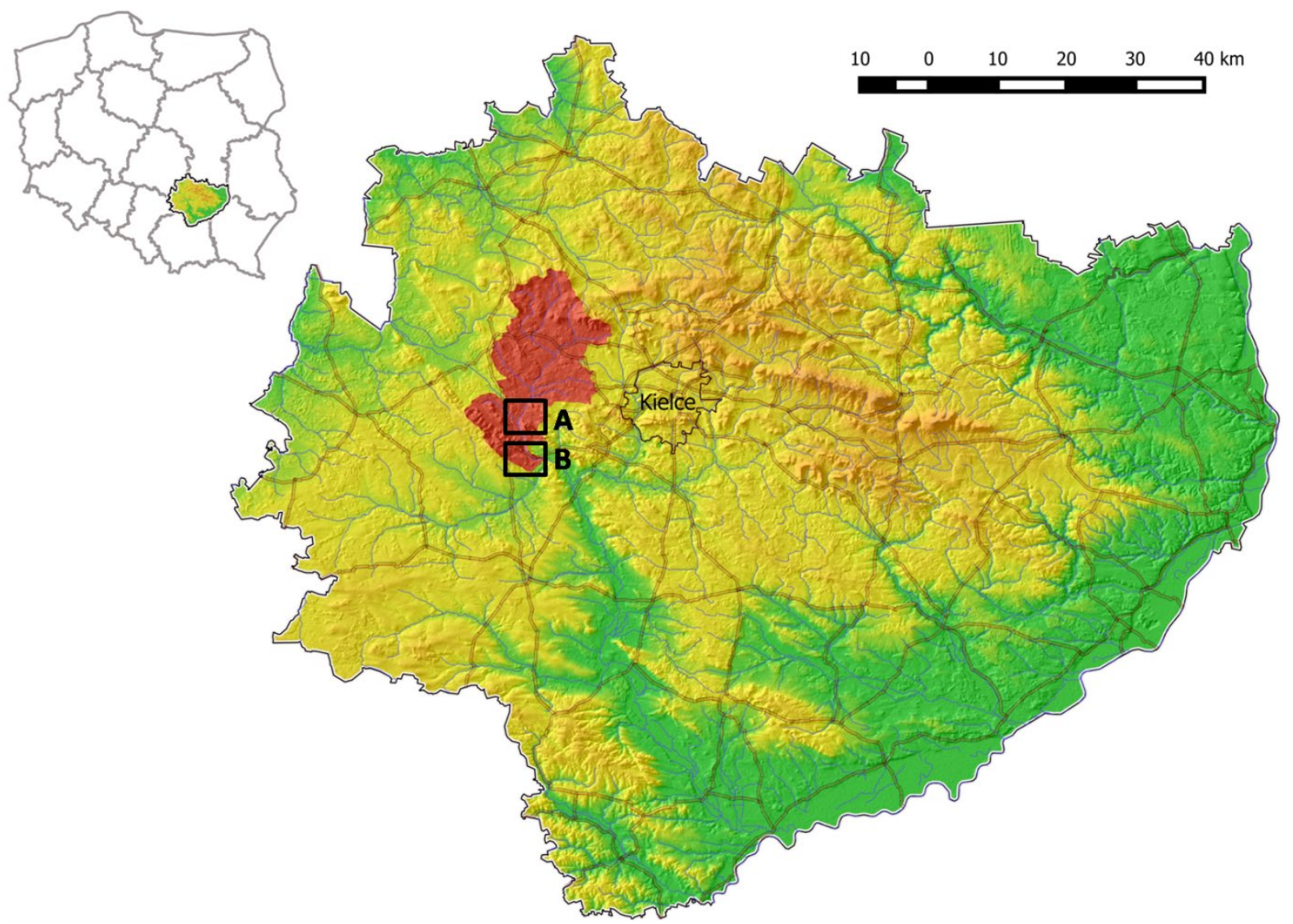

Figure 1. The study area (black qadrats) and Łososina basin (red colour) location in the Digital Elevation Model (DEM) of Świętokrzyskie voivodeship area.

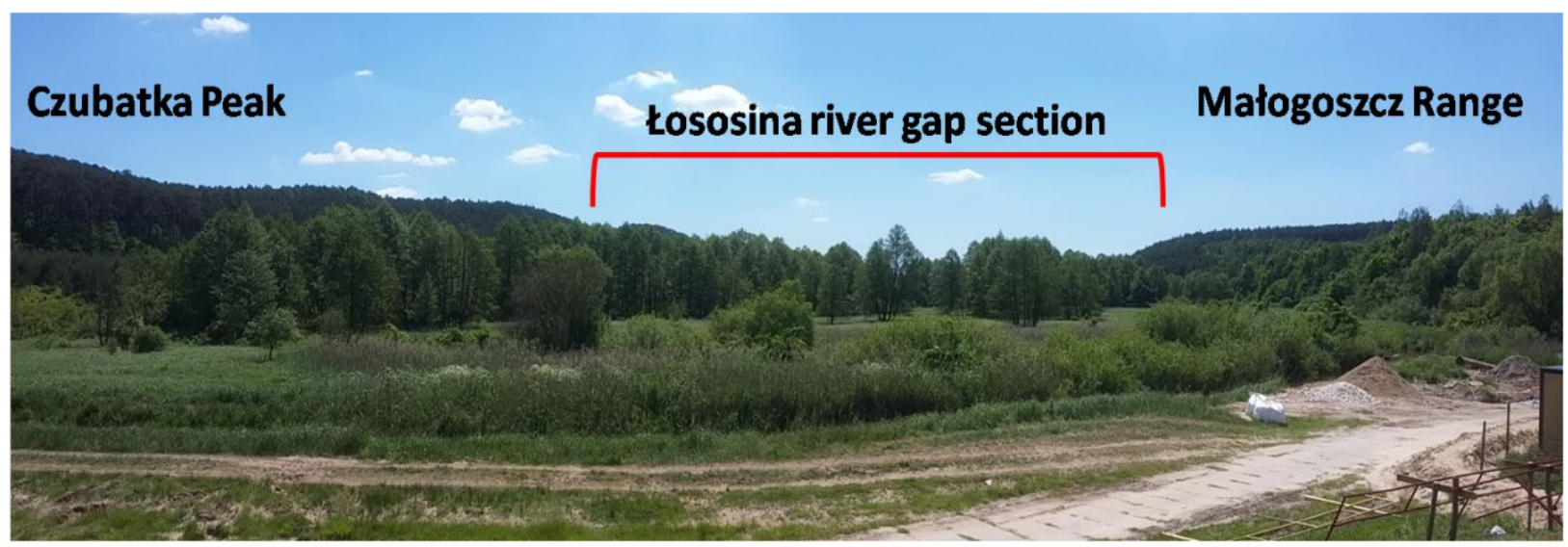

Figure 2. Łosoina river gap section.

\section{MATERIAL AIM OF STUDY}

This study uses geophysical analyzes made by Mala GeoScience's ProEx System (Professional Explorer) GPR. This method is non-invasive method, show the geological surveys of the ground. It is based on the radar counting of high-frequency delays of electromagnetic pulses that are send by the transmitting antenna.

These pulses reflected from various centers (old building foundations, lithofacial boundaries) are then signal back to the receiving antenna counted with the time delay by the central computer device. Due to the subsequent analysis, linear echograms are processed in the program.
The grain size analyzes of sediments were made in the Scientific and Educational Laboratories of the Institute of Geography Jan Kochanowski Universitety in Kielce. For these analysis a set of sieves (DIN ISO 3310/1) and Retsch-Rahmen screens were used.

The results are presented in graphical form in the GRANULOM program, and Folk-Ward's grain size distribution parameters: $\mathrm{Mz}-$ mean size, $\delta \mathrm{I}-$ standard deviation, SkI - skewness, KG - kurtosis were calculated for all samples. Standard radiocarbon dating were made in $14 \mathrm{C}$ Dating Laboratory in Skala. 


\section{RESULTS}

In the valley floor relief are clearly marked different age generations of paleomeanders (Fig. 3) developed from $8230 \pm 90 \mathrm{BP}$; 7415-7061 cal. BC (MKL-3892). Its connected with phase of an increasing the intensity of meandering and the accumulation of point bars at the beginning of the Atlantic. The riverbed was cut off a few hundred years later, as evidenced by the date from the bottom of organic material at $7790 \pm 100 \mathrm{BP} ; 6721$ 6453 cal. BC (MKL-3573) (Fig 4.).

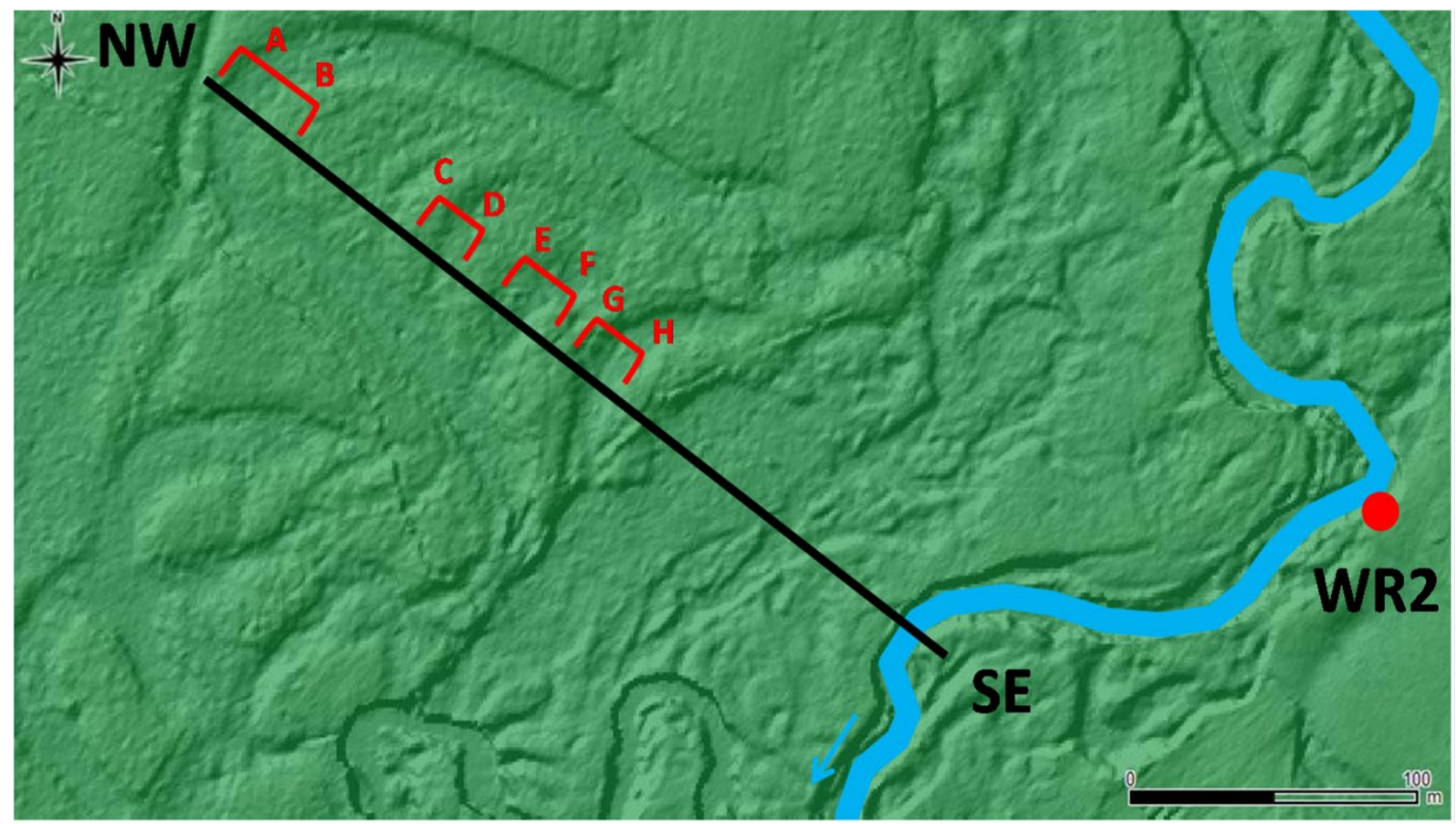

Figure 3. Valea Oii catchment located in north-eastern part of Romania

This intensive lateral migration of the riverbed and its later straightening may have been connected with an increase fluvial activity phase dated to this period in numerous river valleys of the Central Europe [6].

The similar situation is in the left paleomeanders generation. Cut off the riverbed of one of them occurred at the Mesoholocene: $6430 \pm 100 \mathrm{BP}$; 5481-5216 cal. BC (MKL - 4555)(Fig. 5), in with humid climate caused increased aggradation and started filling by peats, just like in other the Holy Cross Mountains rivers, e.g. Trupień.

In the historical times the climate changes led to covering biogenic material by sandy overbank sediments, as evidenced by dates $190 \pm 70 \mathrm{BP} ; 1523$ - 1630 cal. AD (MKL - 4556), similar to Czapłów or Napęków [7]. Organic sediments of oxbow lake fill were covered with overbank deposits after 610 \pm 40 BP; 1290-1409 cal. AD (MKL-3133) (Fig. 6 ). The youngest alluvial bodies are connected with anthropogenic transformation of the riverbed during last centuries. The catchment area was located in the south-western part of the Old Polish Industrial District.

From the Middle Ages to the end of the 19th century there were at least four forges and then water mills, which were built on former forges infrastructure. The activity of the forges and mills led to changes in the river pattern and create an anthropogenic anastomosis.

The GPR analyzes of the valley bottom revealed a dense network of multiage oxbow lakes, which are more or less visible in the relief (Fig. 7).

The geophysical analysis results allow to show precise location of smaller oxbow lakes, previously not detected during field reconnaissance and mapping.

The results of this study will allow to make more detailed research on the Lososina (Wierna Rzeka) valley bottom evolution. 


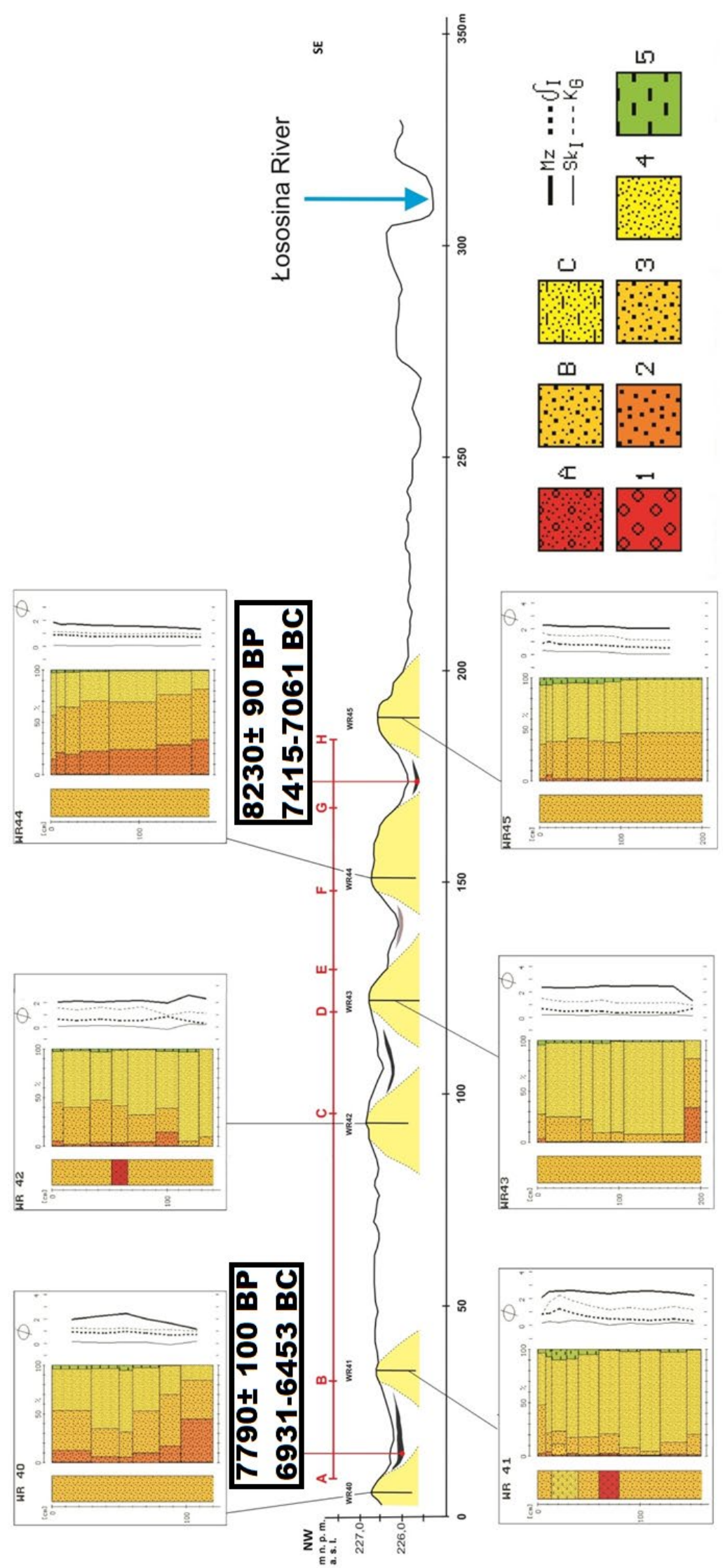

Figure 4. Schematic geological section across sandy series of point bars at Młynki site (location see on Fig. 3) and lithological profiles with grain size and Folk-Ward distribution parameters.

Lithology: A - sands with gravels, B - medium sands, C - silty sands Fractions: 1 - gravel (below $-1 \varphi) ; 2$ - coarse sand $(-1-1 \varphi), 3$ - medium sand $(1-2 \varphi)$, 4 - fine sand $(2-4 \varphi), 5$ - silt and clay (above $4 \varphi)$;

Folk-Ward's grain size distribution parameters: $\mathrm{Mz}-$ mean size, $\delta \mathrm{I}$ - standard deviation, SkI - skewness, KG - kurtosis. 


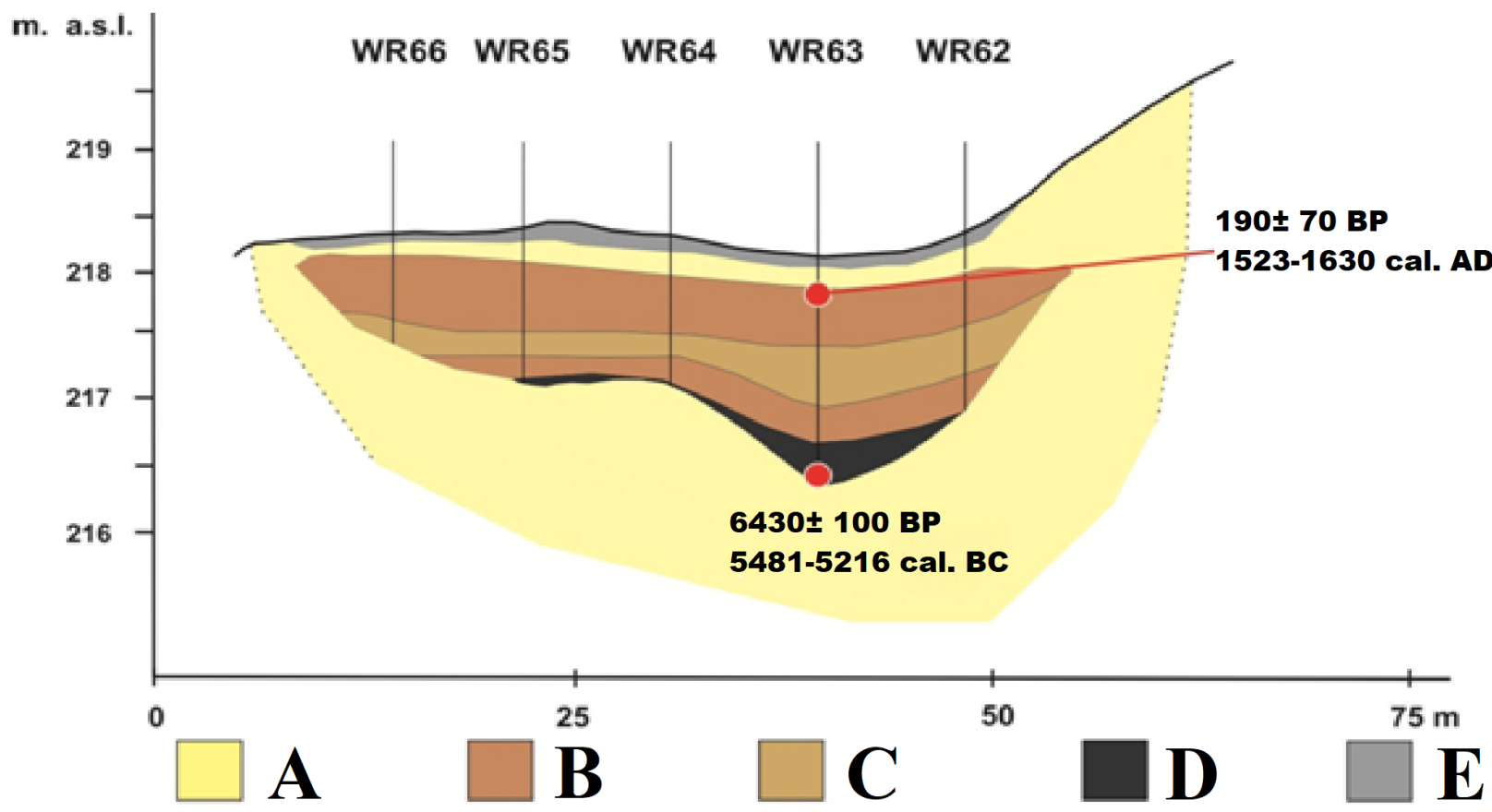

Figure 5. Schematic geological section across paleomeander at Bocheniec I site. A-medium sand; B-siltedpeat; C-poorly decomposed peat; D- highly decomposed peat; E-humus.

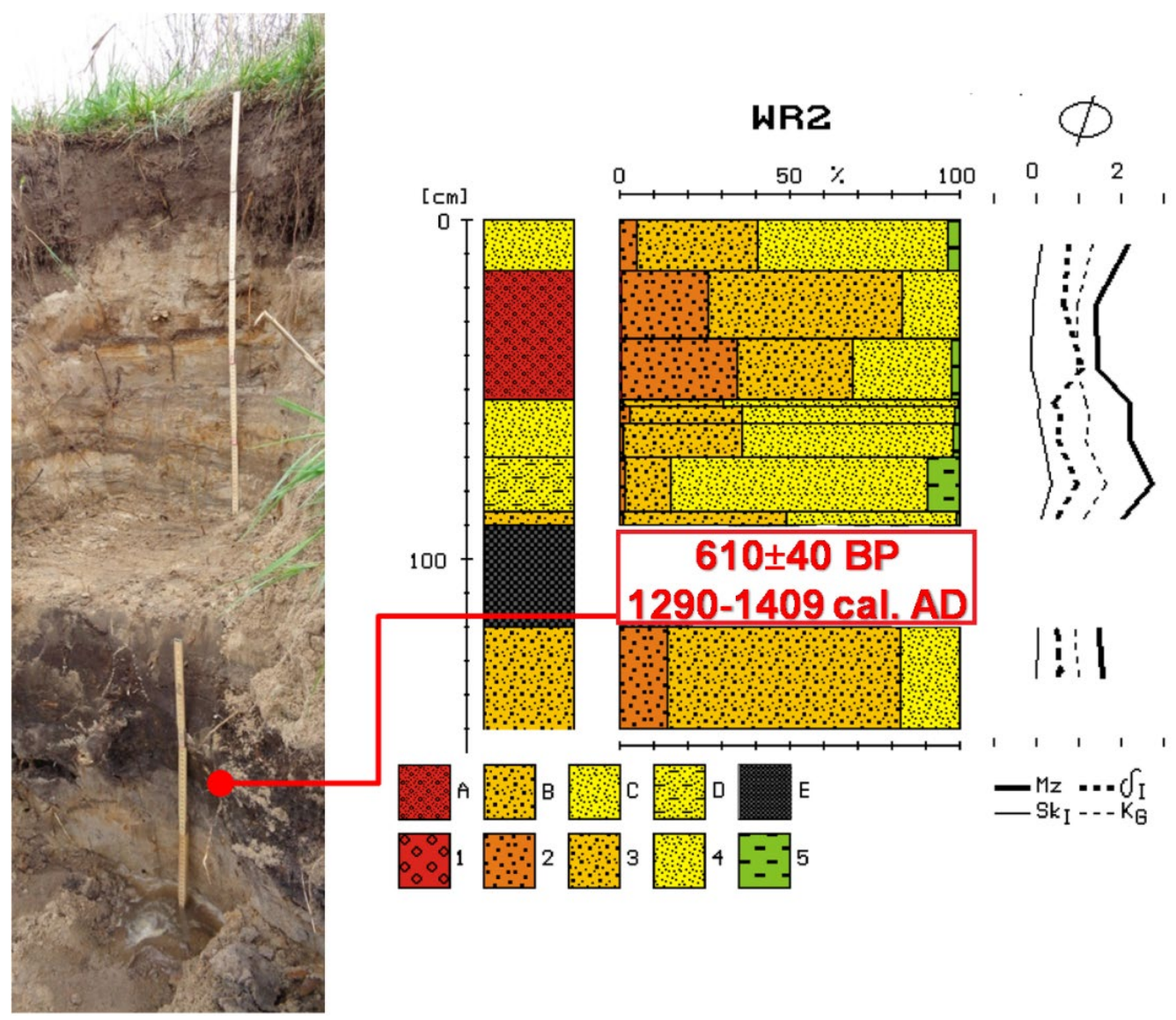

Figure 6. Lithological profiles WR2 at Młynki II site (location see on Fig. 3) with grain size and Folk-Ward distribution parameters and dating.

Lithology: A - sands with gravels, B - medium sands, C - fine sands, D - silty sands, E - highly decomposed peat

Fractions: 1 - gravel (below $-1 \varphi) ; 2$ - coarse sand $(-1-1 \varphi)$,

3 - medium sand $(1-2 \varphi), 4$ - fine sand $(2-4 \varphi), 5$ - coarse silt (above $4 \varphi$ );

Folk-Ward's distribution parameters: $\mathrm{Mz}$ - mean size,

$\delta \mathrm{I}$ - standard deviation, SkI - skewness, $\mathrm{KG}$ - kurtosis. 

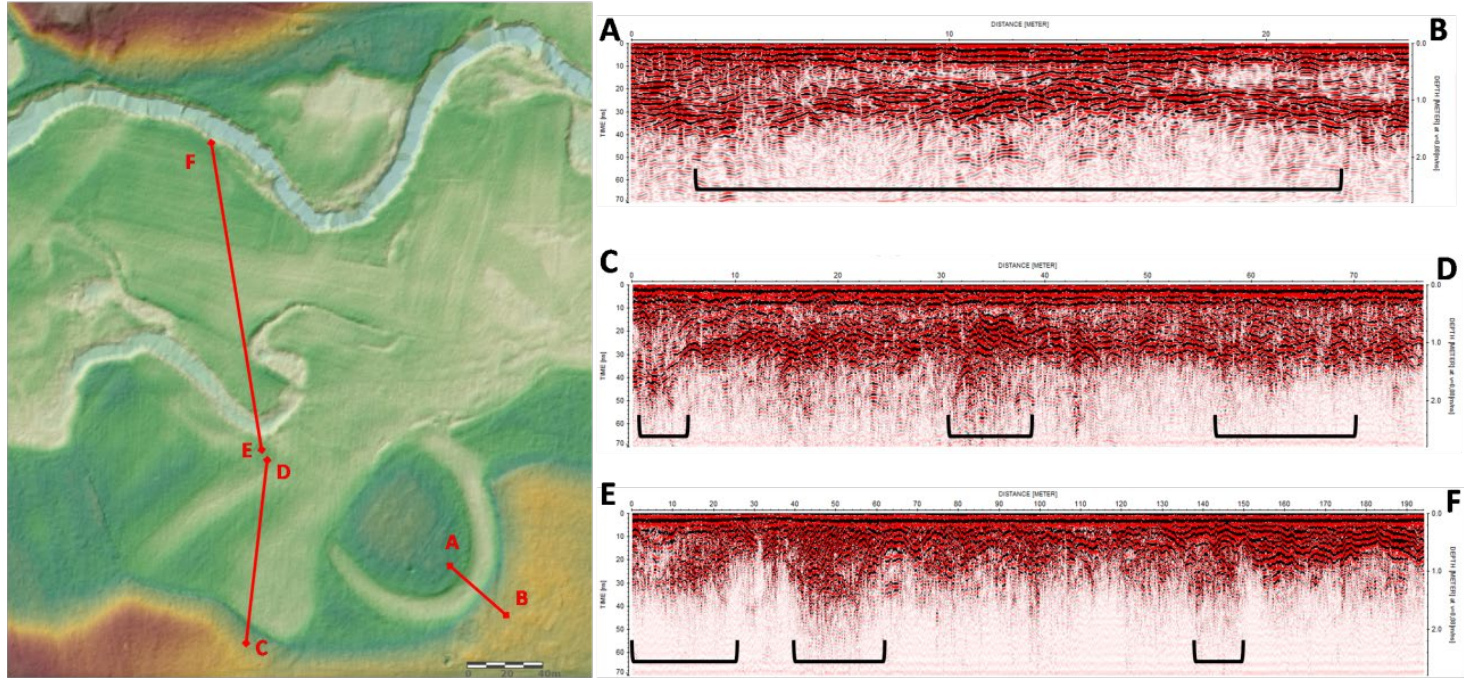

Figure 7. The GPR analyzes of the valley bottom at Bocheniec II site (see qadrat B on Fig. 1) with marked palaeochannels.

\section{CONCLUSIONS}

The phases of increased fluvial activity are clearly marked in the relief and alluvial of the valley floor. Two older dates $(8230 \pm 90 \mathrm{BP} ; 7415-7061 \mathrm{cal}$. BC, $7790 \pm 100 \mathrm{BP}$; 6721-6453 cal. BC) are from the Boreal and Atlantic turn. In these periods analogous changes are visible in many European valleys [6]. The youngest phase can be connected with human activity and the Old Polish Industrial District development, and also with an increase in the frequency and size of floods dating to the period of the Little Ice Age. Changes in the type of sedimentation at the bottom of the valley were not able to prevent the anthropogenic small retention system, i.e. many water reservoirs, channels, or anthropogenic anastomoses, as a result of the four water mills developed on the river. The results of geophysical surveys show the great use fulness of this method in the river valley bottoms study. This results can be helpful in locating and selecting of the study sites for detailed paleogeographic studies.

\section{REFERENCES}

[1] Lindner L., Mastella L., Geneza i wiek przełomu Wiernej Rzeki (Łososiny) w rejonie Bocheńca (SW Obrzeżenie Mezozoiczne Gór Świętokrzyskich). Prace Instytutu Geografii Akademii Świętokrzyskiej w Kielcach, 6, pp 21-46, 2002.

[2] Kondracki J., Regiony fizycznogeograficzne Polski. Wyd. UW, Warsaw, 1997.

[3] Kondracki J., Geografia regionalna Polski. PWN, Warsaw, 2002.

[4] Ciupa T., Współczesny transport fluwialny w zlewni Białej Nidy. Wyd. WSP. Kielce, pp 150, 1991.

[5] Sołtysik R., Geneza mokradeł Gór Świętokrzyskich i Niecki Nidziańskiej. Prace Inst. Geogr. AŚ w Kielcach 9, pp 1-126, 2002.

[6] Kalicki T., Zapis zmian klimatu oraz działalności człowieka i ich rola w holoceńskiej ewolucji dolin środkowoeuropejskich. Prace Geograficzne 204, 2006.

[7] Ludwikowska-Kędzia M., Ewolucja środkowego odcinka doliny rzeki Belnianki w późnym glacjale i holocenie. DIALOG, Warsaw, 2000. 